\title{
NATUR OG MENNESKE I ET SPRÅKLIG KLIMAPERSPEKTIV ${ }^{1}$
}

\author{
KJERSTI FLØTTUM, ØYVIND GJERSTAD OG ANJE \\ MÜLLER GJESDAL \\ Universitetet $i$ Bergen \\ Høgskolen i Østfold
}

\section{SAMMENDRAG}

Med utgangspunkt i et klimaperspektiv undersøker vi i denne artikkelen hvordan nordmenn uttrykker sine meninger om og sitt forhold til den fysiske naturen. Med et materiale i hovedsak hentet fra representative spørreundersøkelser, bestående av svar på åpne spørsmål, stiller vi to spørsmål: 1) hvilken rolle tillegges natur og menneske som årsak til klimaendringer, og 2) hvilken plass har naturen i folks liv og levemåte som et argument for livsstilsendringer. Teoretisk plasserer analysene seg innenfor lingvistisk polyfoni og leksikalsk semantikk. Studien belyser den betydelige kompleksiteten i klimaspørsmålet og peker på de mange spørsmål og valg knyttet til forholdet menneske-natur som deltakerne i vårt demokratiske samfunn må ta stilling til.

\section{[1] INTRODUKSJON}

I den pågående samfunnsdebatten har klimaendringer hatt en viktig plass i flere tiår. Spørsmålene har variert fra å dreie seg om årsaker til mulige, gjennomførbare løsninger for å hindre dramatiske konsekvenser for både natur og mennesker. Den språklige representasjonen og tolkningen av synspunkter har vært preget av både saklige argumenter og mer følelsesladete uttrykksformer. Det siste har vi sett klare innslag av blant annet i debatten om vindmøller på land.

I denne artikkelen studerer vi hvordan nordmenn uttrykker sine meninger om og sitt forhold til den fysiske naturen, i et klimaperspektiv, med utgangspunkt i følgende problemstillinger: 1) hvilken rolle tillegges natur og menneske som årsak til klimaendringer, og 2) hvilken plass har naturen i folks liv og levemåte som et argument for livsstilsendringer. Materialet er svar på åpne spørsmål

[1] Arbeidet er finansiert av Norges forskningsråd, prosjektnr. 283324 
som ble stilt i to spørreundersøkelser i Norsk Medborgerpanel/DIGSSCORE, Universitetet i Bergen. I den første av disse undersøkelsene, gjennomført i 2018, stilte vi spørsmålet: «Hva tenker du når du hører eller leser ordet "klimaendring'?». I den andre, gjennomført i 2019, var spørsmålet: «Har du endret din levemåte for å bidra til å begrense skadelige klimaendringer?». De som svarte positivt på dette, fikk følgende oppfølging: «Vi vil gjerne at du forteller oss hva som har motivert deg til å endre din levemåte.»

Forholdet til naturen har fått fornyet aktualitet $\mathrm{i}$ forbindelse med pågående utbygging av vindkraft som medfører inngrep i naturområder. For noen vil enkelte klimatiltak være uakseptable dersom de fører til naturskader, og det er derfor viktig å få en bedre forståelse av hvordan hensynet til naturen fungerer som et politisk argument. Tidligere forskning (Dryzek 2013; Andersen 2017) har sett på rådende «ideologier» i miljødebatten. Med ideologier menes her en helhetlig forståelse av miljøproblemene, som svarer til bestemte politiske posisjoner og argumenter. For Dryzek er de viktigste posisjonene det han kaller «bærekraftig utvikling» og «økologisk modernisering», som begge har vært og er viktige i norsk miljøpolitikk. I økologisk modernisering inngår staten i samarbeid med næringsliv, fagbevegelse og miljøorganisasjoner for å utvikle teknologiske og økonomiske verktøy som kan begrense skader på miljø og natur. I denne modellen er natur og økologisk balanse først og fremst viktig av hensyn til menneskers behov, og det anses som mulig å løse miljøproblemene innenfor rammene av dagens økonomiske system. I sin studie av norske stortingsdebatter, finner også Andersen (2017) at et slikt gjennomslag for den økologiske moderniseringen skjer i løpet av 90-tallet. Mens økologisk modernisering har fătt stort gjennomslag i offisiell politikk, finnes det også en "grønn radikalisme» (Dryzek 2013, del V) som fokuserer på en mer radikal holdningsendring når det gjelder miljø og klima, enten det gjelder livsstilsendring hos enkeltpersoner eller påvirkning av beslutningstakere. I et slik perspektiv vil naturens egenverdi ha status som selvstendig politisk argument. Mens økologisk modernisering altså har fått politisk gjennomslag, er grønn radikalisme noe en heller finner blant annet i miljøorganisasjoner og utgjør en mer marginal posisjon. Det er derfor en posisjon som kan være vanskelig å studere i korpus som ellers ofte brukes for å utforske dagsaktuelle tema, som Norsk aviskorpus eller Talk of Norway, som gjerne speiler mer utbredte og etablerte oppfatninger. Med dette som utgangspunkt er det interessant å undersøke hva som uttrykkes når respondenter fritt og spontant får muligheten til å uttrykke sine holdninger i spørreundersøkelser. Er det slik at man i hovedsak holder seg innenfor rammene av økologisk modernisering, som har vært så sentral i den norske miljødebatten, eller finnes det også 
spor av grønn radikalisme? Resultater fra undersøkelsen vil bidra til den kunnskapsbasen som er nødvendig for all type beslutningstaking knyttet til klimaendringer, på ulike nivåer i samfunnet. Det er viktig at klimatiltak har forankring i folkelig oppslutning, og det er derfor viktig med mer kunnskap om hvordan forholdet til naturen spiller inn i motstand mot utviklingen av nye tiltak.

I det videre gjør vi først rede for vårt teoretiske rammeverk (2) og materiale og metode (3), deretter gjennomfører vi en polyfonianalyse (4) og en leksikalsksemantisk analyse (5) av utvalgte eksempler. I seksjon (6) oppsummerer og diskuterer vi resultatene.

\section{[2] Teoretisk ramme}

På grunn av datamaterialets heterogene art - fritt formulerte svar på to forskjellige åpne spørsmål - velger vi en todelt teoretisk innramming. Den ene delen av analysen bygger på teorien om lingvistisk polyfoni, mens den andre bygger på leksikalsk semantikk.

\section{[2.1] Lingvistisk polyfoni}

Lingvistisk polyfoni, nærmere bestemt varianten kalt ScaPoLine (den skandinaviske polyfoniteorien), utviklet av Nølke et al. (2004), har sitt utspring i fransk utsigelseslingvistikk (Ducrot 1984; Gjerstad 2011). Ifølge denne teorien fins det en rekke språklige markører som inkluderer andre stemmer enn talerens i en og samme ytring. Det mest eksplisitte eksemplet på dette er sitater eller gjengitt tale, som det knapt fins noen eksempler på i materialet. En annen viktig polyfonimarkør er nektelsen, hvor taleren tilbakeviser et underliggende positivt synspunkt. Dette har vi i det følgende eksemplet (vi presiserer at alle eksemplene vi viser til i analysene er autentiske gjengivelser fra datamaterialet):

(1) naturlige klimaendringer, der det meste ikke er menneskeskapt

Ifølge ScaPoLine består et synspunkt (sp) av tre komponenter, nemlig kilde, bedømmelse og innhold, som kombineres på følgende vis i analysen: [KILDE] (BEDØMMELSE (Innhold)). I analyse av nektelsen opptrer disse tre komponentene på følgende vis i den polyfone konfigurasjonen:

sp1: [X] (SANT (Det meste er menneskeskapt))

sp2: [avsender] (USANT (sp1))

Ut fra ytringens språklige egenskaper er det ikke mulig å se hvem som står bak sp1; derfor er kilden markert med «X», som symboliserer at kilden er tom. Nektelsen signaliserer altså at det er noen som er ansvarlig for sp1, men den gir ikke 
noe informasjon om identiteten til den eller de som kan tillegges dette synspunktet.Den delen av tolkningen er avhengig av mottakers evne til å mobilisere relevant kontekstuell kunnskap i tolkningsprosessen.

Skillet mellom bedømmelse og innhold gjør ScaPoLine i stand til å beskrive nyansene i markørenes logisk-semantiske instruksjoner. Dette kan illustreres ved å sammenligne nektelsen med adverbet kanskje, som markerer epistemisk modalitet. Ytringen 'Det meste er kanskje menneskeskapt' har følgende konfigurasjon:

sp1: [X] (SANT (Det meste er menneskeskapt))

sp2: [avsender] (KANSKJE (sp1))

Hvis vi sammenligner denne konfigurasjonen med nektelsen, ser vi at den fundamentale hierarkiske strukturen er lik, hvor sp2 inkluderer en bedømmelse av sp1, som har en tom kilde. Det er imidlertid et sentralt element som er forskjellig, nemlig forholdet mellom avsender og sp1. Mens dette synspunktet avvises kategorisk ved bruk av nektelsen, opprettholdes det som en mulighet ved bruk av kanskje, men uten at avsender tar på seg ansvaret for at det er sant. ScaPoLine er altså i utgangspunktet et verktøy for lingvistiske beskrivelser på syntaktisk og leksikalsk nivå. Imidlertid er det mindre behov for et slikt finmasket verktøy i analysen av tekster, hvor det er mer verdifullt å peke på ytringenes argumentative eller retoriske implikasjoner i et større perspektiv. Derfor velger man ofte å kombinere bedømmelse og innhold i slike analyser, noe vi også kommer til å gjøre her. Dermed får nektelsen følgende konfigurasjon:

sp1: (X) Det meste er menneskeskapt

sp2: (avsender) sp1 er usant

I tillegg til polyfonimarkørene vi har sett på så langt, spiller argumentative konnektorer en viktig rolle i ScaPoLine. Her er konnektoren men sentral. Denne innrømmende konnektoren spiller i likhet med nektelsen en viktig rolle for å signalisere uenighet, men den gjør det på mer subtilt vis. La oss se på eksempel (2):

(2) Umoralske utnyttelse av naturens ressurser, sosialt pålagt tvang til å vise til en viss økonomisk frihet f. eks. 2 biler, utlandsk reiser, kjøtt på middagsbordet. Klimaendringer er naturlig for jordens ekosystemet, men mennesker påskynder det.

Respondenten stiller seg kritisk til menneskelig forbruksmønster, og fremstiller det som en årsak til klimaendringer. Dette følges av innrømmelsen «klimaendringer er naturlig for jordens ekosystemet», som første ledd i strukturen ' $a$ 
men $b^{\prime}$. Motargumentet $b$ er «mennesker påskynder det», som i kraft av å følge men, fremstilles som det mest tungtveiende argumentet i strukturen. Selv om de to argumentene ikke står i et direkte motsetningsforhold til hverandre, dvs. at begge kan være sanne, står de i et indirekte motsetningsforhold gjennom å orientere seg mot to gjensidig utelukkende konklusjoner, angitt som $c$ og ikke-c i analysen under. Disse konklusjonene er ikke eksplisitt til stede i den innrømmende strukturen, men er et resultat av konnektorens semantiske instruksjoner, som inviterer mottaker til å resonnere seg frem til dem, gjennom såkalte topoi. Et topos har formen 'hvis $a$ så b', og er av generell verdi, ut over den spesifikke situasjonen som ytringen omhandler. Slik kan et topos fungere som implisitt oversetning i et entymem: 'Det er fint vær, altså går Per tur' (oversetning: 'hvis det er fint være går Per tur') (Nølke et al. 2004, s. 87-90). Ved bruk av innrømmende men får vi to slike topoi, altså argumenter med generell gyldighet, gjengitt som sp2 og sp4 i konfigurasjonen under. Det er et kollektivt MAN som utgjør kilden til disse synspunktene (ibid. 92-96):

$\begin{array}{ll}\text { sp1: (X) } a: & \text { Klimaendringer er naturlig for jordens ekosyste- } \\ & \text { met } \\ \text { sp2: (MAN) } & \text { Hvis } a \text {, så } c \\ \text { sp3: (respondent) } b: & \text { mennesker påskynder klimaendringer } \\ \text { sp4: (MAN) } & \text { Hvis } b \text {, så ikke-c }\end{array}$

Siden sp1 utgjør innrømmelsen i strukturen, har dette synspunktet et annet opphav enn respondenten selv. Når det gjelder sp2 og sp4, utgjør de kollektive synspunkter, dvs. generelle sannheter som er gjenstand for enighet blant en større eller mindre gruppe. Disse synspunktene er nettopp konstruert som kollektive fordi de utgjør fundamentet for argumentasjonen. Spørsmålet er hvordan argumentene $c$ og ikke-c kan formuleres slik at sp2 og sp4 svarer til generelt aksepterte sannheter, på en måte som også har relevans for dette spesifikke tilfellet. En mulighet er at disse konklusjonene omhandler menneskelig handlingsrom i klimaspørsmålet:

sp2: (a) Hvis klimaendringer er naturlig for jordens økoystem, så (c) kan ikke mennesker gjøre noe med dem.

sp4: (b) Hvis mennesker påskynder klimaendringer, så (ikke-c) kan de gjøre noe med dem.

Siden sp3 fremstilles som det mest relevante i det aktuelle tilfellet, vil den innrømmende konstruksjonen som helhet orientere seg mot konklusjonen 'mennesker kan gjøre noe med klimaendringene'. Dette er altså et resultat av argumentenes plassering i strukturen. 


\section{[2.2] Leksikalsk semantikk}

Polyfoniteori er velegnet til å analysere epistemiske utsagn om klimaendringer, men for å analysere utsagn som er mer evaluerende bruker vi et teoretisk rammeverk basert på leksikalsk semantikk, nærmere bestemt begrepet om semantisk prosodi (Louw 1993; Partington 2004; Hunston 2007b). Louw (1993) bygger dels på John Sinclairs empiriske arbeider innen korpuslingvistikk (blant annet Sinclair 1987, sitert av Louw 1993), som fokuserer på leksikalske mønstre og som i personlig kommunikasjon med Louw (Louw 1993, s. 158) omtales som semantisk prosodi. Louw definerer semantisk prosodi som «A consistent aura of meaning with which a form is imbued by its collocates [...]» (Louw 1993: 157). Begrepet prosodi er hentet fra fonologien, og det kan brukes mer generelt om språklige fenomener som uttrykkes over mer enn én språklig enhet (Partington et al. 2013, s. 58). På liknende vis vil for eksempel kollokasjoner, det vil si ord som har en tendens til å opptre sammen, påvirke hverandres semantiske verdi, men prosodien kan også fungere på tekstnivå. For Louw er dette fenomenet ikke tilgjengelig for introspeksjon, men ved å undersøke ordenes bruk slik de opptrer i faktiske korpus vil en kunne identifisere typiske mønstre. I sin studie undersøker Louw ord som ikke har en iboende negativ verdi, som adjektivet utterly og flerordsuttrykket bent on. Louw finner at disse typisk opptrer med negativt vurderte uttrykk i korpuset han studerer, slik at det skapes en negativ semantisk prosodi, noe som ikke nødvendigvis ville være klart fra en analyse basert på introspeksjon. Begrepet om semantisk prosodi er derfor basert på to helt grunnleggende prinsipper; at prosodien eller meningen skapes gjennom et samspill mellom flere uttrykk (typisk kollokasjoner), og at den ikke er tilgjengelig for introspeksjon, men må utforskes gjennom analyser av faktiske forekomster i korpus. Ved å sammenlikne uttrykk i en tekst man ønsker å analysere med et større korpus, vil man kunne få frem hva som kjennetegner bruken av uttrykket når det gjelder semantisk prosodi.

Semantisk prosodi har vært omdiskutert (Hunston 2007a), blant annet på grunn av at det er uenighet om hvilket nivå det befinner seg på (kollokasjon eller tekst), og om det er snakk om et binært forhold mellom positiv eller negativ prosodi, eller en mer kompleks, gradvis form for prosodi (ibid.). Av plasshensyn følger vi Partington et al. (2013: 58), som analyserer evaluerende prosodi med utgangspunkt i rammeverket korpusassistert diskursanalyse der korpuslingvistiske metoder brukes til å utforske fenomener på diskursnivå, som metafor, evaluering og fremstilling av sosiopolitiske tema (ibid.). Gjennom å fokusere på evaluerende prosodi undersøker Partington et al. (2013) hvordan vekselvirkningen mellom flere språklige uttrykk som uttrykker evaluering skaper en effekt på 
tekstnivå som i sin tur gjør at tekstene fremstår som henholdsvis positive/optimistiske eller negative/pessimistiske. I vår analyse av evaluering undersøker vi også hvordan følelser uttrykkes i teksten. Følelser, eller emosjon, er et komplekst psykologisk og kulturelt fenomen, og den språklige fremstillingen er tilsvarende kompleks (se f.eks. Wierzbicka 1992). Vår undersøkelse av språklige uttrykk for følelser er derfor eksplorativ, og fokuserer på eksplisitte språklige uttrykk for følelser, som kan knyttes til positiv eller negativ evaluering (redd, skam og kjcerlighet er eksempler fra vårt korpus), og hvordan disse opptrer sammen med, og bidrar til, evalueringen. Følelser er viktige i debatter om klima, natur og miljø, men diskursanalyser fokuserer ofte mest på den argumentative, saksorienterte siden av debattene (Breeze 2019). Analyser av den språklige representasjonen av følelser kan derfor være et nyttig supplement for å gripe kompleksiteten i debatten.

\section{[3] Materiale og metode}

Materialet som utgjør det empiriske grunnlaget for denne studien er hentet fra to nasjonalt representative spørreundersøkelser gjennomført ved Norsk Medborgerpanel/DIGSSCORE, Universitetet i Bergen. I begge undersøkelsene utgjør materialet tekstsvar på åpne spørsmål, hvor respondentene svarer fritt med hensyn til både innhold og lengde. Åpne spørsmål gir et rikere og mer nyansert materiale enn ved lukkede spørsmål med opplisting av svaralternativer (Fløttum (ed.) 2017; Langaas et al. 2020; Stoneman et al. 2012; Tvinnereim \& Fløttum 2015; Tvinnereim et al. 2017). Materialet som danner utgangspunkt for første problemstilling er svar på følgende spørsmål, stilt i 2018: «Hva tenker du når du hører eller leser ordet 'klimaendring'?»

Vår analyse er i hovedsak av kvalitativ art, med noe støtte i en kvantitativ tilnærming. For den kvalitative analysen begrenset til problemstillingen ovenfor, hentet vi ut de 64 svarene som inneholdt både en form av natur (natur*) og en form av substantivet menneske eller adjektivet menneskeskapt (menneske*). Materialet for den andre problemstillingen hentet vi fra et eksperiment gjennomført i 2019, hvor respondentene først fikk spørsmålet «Har du endret din levemåte for å bidra til å begrense skadelige klimaendringer?» og hvor de som svarte positivt på dette, fikk følgende oppfølging: «Vi vil gjerne at du forteller oss hva som har motivert deg til å endre din levemåte.» Av de 876 «fortellingene» dette resulterte i, hentet vi ut de 74 som inneholdt natur*. Med disse dataene som utgangspunkt foretar vi en kvalitativ analyse hvor vi kombinerer polyfoniteori med en leksikalsk-semantisk tilnærming.

Selv om materialets omfang er begrenset, mener vi det kan gi interessant inn- 
sikt i hvordan naturen gjøres relevant i klimasammenheng blant et bredere publikum, fordi den åpne spørsmålsformen gir rom for spontane reaksjoner. Språkvitenskapelig er dette også interessant, fordi data fra spørreundersøkelser kan representere en mer uformell skriftlig teksttype enn det en finner i mer etablerte korpus for norsk, som for eksempel Norsk aviskorpus (Andersen \& Hofland 2012) eller KIAP-korpuset (Fløttum, Dahl \& Kinn 2006). Materialet kan derfor gi grunnlag for å studere språklige representasjoner av evaluering og følelser i klimasammenheng, noe som kanskje lettere kommer til uttrykk i spontan og uformell tekstproduksjon enn i mer formelle tekstuttrykk som avisartikler og vitenskapelige artikler.

Vi mener undersøkelsen kan bidra til en mer nyansert forståelse av hvordan sakkunnskap, følelser og evaluering virker sammen i ytringer om klimaforhold, og her spesielt om relasjonen menneske-natur.

Svarene på det første spørsmålet er i stor grad av epistemisk karakter, ettersom spørsmålet om årsaker til klimaendringene dreier seg om sikker/usikker viten eller kunnskap. Svarene på det andre er av mer personlig art og vil være preget av verdiladete og emosjonelt pregete uttrykksformer. Dette tilsier at vi velger ulike teoretisk-metodiske tilnærminger i analysen av svarene på de to spørsmålene.

Når respondentene ytrer seg om forholdet mellom menneskelige og naturlige faktorer som årsaker til klimaendringer, velger noen å formulere argumenter til fordel for det ene eller det andre standpunktet. Alternativt kan de tilbakevise eller vise støtte til andres synspunkter i debatten, enten eksplisitt eller implisitt. Det første spørsmålet legger med andre ord opp til svarformuleringer som er argumentative, og som forholder seg til andre stemmer. Dette gjør polyfoniteori (Nølke et al. 2004) til et velegnet verktøy for analysen av slik språkbruk. Denne teorien analyserer nettopp argumentasjonsmarkører, modale adverb, nektelser og gjengitt tale som uttrykk for talerens forhold til andre stemmer, noe vi skal se nærmere på i seksjon 4 .

I 2018, det samme året som Norsk medborgerpanel (NMP, se ovenfor) stilte spørsmålet til sine respondenter om hva de forbinder med ordet klimaendring, gjennomførte Cicero, Senter for klimaforskning, en norsk spørreundersøkelse om klimaendringer, med 4057 respondenter. ${ }^{2}$ Blant annet ble deltakerne spurt om hva de mente om følgende påstand: «Menneskelig aktivitet påvirker ikke klimaet». 68,5 prosent mente dette stemmer svært eller ganske dårlig, mens 11,0 prosent mente påstanden stemmer svært eller ganske godt. Selv om slike spør-

[2] «Folk og klima: Nordmenns holdninger til klimaendringer, klimapolitikk og eget ansvar» (https://pub.cicero.oslo.no/cicero-xmlui/bitstream/handle/11250/2634149/Rapport\%202019\%2020\%20HQweb.pdf?sequence=6\&isAllowed=y) 
reundersøkelser gir et viktig bilde på hvilke forestillinger som eksisterer omkring klimaspørsmålet i samfunnet, gir ikke svarkategoriene grunnlag for å fange opp nyansene i respondentenes oppfatninger. I hvilken grad anser respondentene klimaendringene for å være menneskeskapte i motsetning til naturlige? I hvilken grad er de sikre på at deres egne synspunkter stemmer med virkeligheten? Slike nyanser fremkommer i vårt materiale med svar på åpne spørsmål samlet inn fra NMP.

Materialet i seksjon 5 består av åpne svar hvor respondentene forklarer hva som har motivert dem til å endre levemåte for å bidra til å begrense skadelige klimaendringer, og hvor den trunkerte formen natur* forekommer. I dette materialet er det altså foretatt et utvalg av respondenter som kan antas å være mer engasjert i temaet enn andre, i og med at de har valgt å gjøre livsstilsendringer. Det er med andre ord snakk om et verdispørsmål, hvor både følelser og moralske vurderinger er involvert. Vi er derfor interessert i hvordan denne evalueringen uttrykkes. Språklig sett anser vi evaluering så enkelt som at noe er «godt» eller «dårlig» (se Partington et al. 2013: 43). Som Hunston (2004, 2007a) har vist, er imidlertid ikke evaluering bare lokalisert i enkeltuttrykk, men er ofte en kumulativ effekt av at flere uttrykk (adjektiv, substantiv, verb) opptrer sammen, også sammen med flerordsuttrykk (som ta vare på). Vi analyserer derfor hvordan evaluerende uttrykk opptrer sammen for å skape tekstens semantiske prosodi (Louw 1993; Partington 2004; Hunston 2007b).

For å undersøke den evaluerende prosodien, sammenligner vi uttrykk fra vårt korpus med Norsk aviskorpus (Andersen \& Hofland 2012) der det er relevant. Dette er et monitorkorpus, altså et korpus som kontinuerlig oppdateres med nytt materiale, med tekster fra norske aviser. Korpuset dekker perioden fra 1998 til i dag, og teller 1952671824 ord på analysetidspunktet. Norsk aviskorpus kan antas å være representativt for norsk språkbruk og er dermed en god kilde for å utforske ords mening i bruk. På grunn av korpusets størrelse, og for å gjøre analysen håndterlig, avgrenser vi utvalget til året 2019, som er det samme året som våre data ble innhentet.

[4] NATURLIGE ELLER MENNESKESKAPTE KLIMAENDRINGER: EN POLY-

FONISK ANALYSE AV RESPONDENTENES AVVEININGER OG PÅSTANDER Når man diskuterer hvorvidt mennesker eller natur har størst påvirkning på klimaet, er det nærliggende å gjøre det gjennom å signalisere enighet eller uenighet med andre stemmer, enten eksplisitt eller implisitt. Derfor tar den første analysen utgangspunkt i språklige polyfonimarkører. Før vi analyserer eksempler med slike markører skal vi se mer generelt på betydningsforholdet mellom natur og mennesker hos de forskjellige respondentene. Gjennom analyser av alle svar 
som drøfter årsakene til klimaendringene, og som inneholder ordene menneske* og natur*, kom vi frem til følgende hovedkategorier:

\begin{tabular}{ccccc}
\hline $\begin{array}{c}\text { Kate- } \\
\text { gori }\end{array}$ & $\begin{array}{c}\text { Natur og men- } \\
\text { nesker likestilt }\end{array}$ & $\begin{array}{c}\text { Natur viktigere } \\
\text { enn mennesker }\end{array}$ & $\begin{array}{c}\text { Mennsker vikti- } \\
\text { gere enn natur }\end{array}$ & $\begin{array}{c}\text { Usik- } \\
\text { kerhet }\end{array}$ \\
\hline Antall & 23 & 16 & 9 & 16 \\
\hline
\end{tabular}

TABELL 1. KLIMAENDRINGER - ÅRSAKSKATEGORIER BLANT SVAR SOM INNEHOLDER MENNESKE* OG NATUR*

De følgende eksemplene illustrerer hver av de fire kategoriene:

(3) a. FN Klimapanel Naturlige endringer Menneskelig påvirkning (kategori 1)

b. Har forekommet til alle tider, og er drevet av naturen selv, i mye større grad enn det er menneskeskapt. Miljø-ødeleggelser, derimot.. (kategori 2)

c. Menneskeskapte endringer og noe naturlige endringer. (kategori 3)

d. Er den menneskeskapt eller er det naturlige klimasvingninger, er kanskje en kombinasjon? Uansett så må verdens befolkning ta grep for å redusere utviklingen. (kategori 4)

I tillegg til disse fire kategoriene, fins det svar som omtaler naturen alene som årsak til klimaendringer (1 forekomst), og menneskelig aktivitet alene som årsak til klimaendringer ( 16 forekomster). Disse er imidlertid ikke inkludert i tabellen, fordi vi ønsker å se nærmere på de svarene hvor begge disse faktorene fremstilles som årsaker eller mulige årsaker. Hvordan veies de to opp mot hverandre, hva er graden av usikkerhet i respondentens bedømmelse av spørsmålet, og hvilke spor av den større debatten finner man i de enkelte svarene?

La oss først se på det store bildet. I de 64 svarene finner vi til sammen ni nektelser, hvorav seks befinner seg i svar som hører inn under kategori 2 (de resterende fordeler seg slik: en i kategori 1 og to i kategori 4). Utvalget er lite, uten noen grad av statistisk signifikans, men man kan likevel merke seg at nektelsene i kategori 2 brukes som regel for å motsi synspunkter om at klimaendringene er et vesentlig problem, eller at vi har sikker kunnskap om fenomenet:

(4) Klimaet endrer seg naturlig, vi ser en oppvarming som kan være mennes keskapt, men dette kan også skyldes naturlige variasjoner. Vi har ikke lange nok måleperioder for klimaet til å være så bastante som politikerne er. 
Som beskrevet i seksjon 2, skaper nektelsen et implisitt synspunkt, som tilbakevises av avsender:

sp1: (X) Vi har lange nok måleperioder for klimaet til å være så sikre som politikerne er ${ }^{3}$

sp2: (respondent) sp1 er usant

Som nevnt er kilden til sp1 i utgangspunktet ukjent, men koteksten indikerer at det kan tillegges politikerne. Eksemplene (5a-5c) skaper et tilsvarende motsetningsforhold, gjennom nektelsen $i k k e$, mellom respondentens eget synspunkt og synspunkter med vag eller ukjent kilde.

(5) a. tror mer på naturlige svingninger, enn att alt er menneske skapt.vi har hatt både istid og issmelting, og da var vel ikke global oppvarming noe problem.

b. Temperaturen stiger, noen mener de vet hvorfor, men deres be regningsmodellene tar ikke høyde av naturlige signinger (slik som vi har hatt før når det var grønt og frodig på Grønland) og kan ikke forklare hvorfor naturlige svingninger oppstår og hvorfor, og fokus blir ensidig på menneskeskapt $\mathrm{CO} 2$ (som i og for seg er bra, men forskningen blir veldig ensidig).

c. At det mennesket har skapt, er lite, og ikke står i forhold til detsom naturlig oppstår, og er følgelig et medieskapt problem, i hovedsak.

Den innrømmende konnektoren men gjør seg også gjeldende i de 64 svarene, hvor vi finner hele 22 forekomster. La oss først se på den innrømmende konstruksjonen som vi analyserte i 2.1, og som også faller inn under kategori 2:

(6) Umoralske utnyttelse av naturens ressurser, sosialt pålagt tvang til å vise til en viss økonomisk frihet f. eks. 2 biler, utlandsk reiser, kjøtt på middagsbordet. Klimaendringer er naturlig for jordens ekosystemet, men mennesker påskynder det.

sp1: (X) $a$ :

sp2: (MAN)

sp3: (respondent) $b$ : mennesker påskynder klimaendringer

[3] Et synspunkt består ikke av en syntaktisk konstruksjon men et semantisk innhold. Dermed er det heller ikke nødvendig å gjengi det positivt underliggende synspunktet med de samme syntaktiske eller leksikalske egenskapene som ytringen. I dette tilfellet ville en slik gjengivelse fremstå som unaturlig, gitt at bastant er et negativt konnotert adjektiv som tjener til å svekke troverdigheten til sp1: 'Vi har lange nok måleperioder for klimaet til å være så bastante som politikerne er'. 
sp4: (MAN) Hvis b, så ikke-c

Siden det andre argumentet ('mennesker påskynder det') fremstilles som det mest relevante i det aktuelle tilfellet, vil den innrømmende konstruksjonen som helhet orientere seg mot konklusjonen 'mennesker kan gjøre noe med klimaendringene'. Dette er altså et resultat av argumentenes plassering i strukturen. Hvis vi sammenligner denne konklusjonen med svarets kategoritilhørighet, som er 'natur viktigere enn mennesker', ser vi en interessant kontrast mellom betydningen som tillegges naturlige klimaendringer, og den argumentative tyngden som tillegges den menneskelige faktoren.

Vi finner et motsatt forhold mellom innhold og argumentativ orientering i det følgende eksemplet, som faller inn under kategori 3, «mennesker viktigere enn natur»:

(7) At det meste av det kommer fra menneskene, men det er mye som kommer fra naturen, vulkanutbrudd, jordskjelv og sikkert andre ting.

$\begin{array}{ll}\text { sp1: (X) } a: & \text { Det meste av det kommer fra menneskene } \\ \text { sp2: (MAN) } & \text { Hvis } a \text {, så } c \\ \text { sp3: (respondent) } b: & \text { det er mye som kommer fra naturen, vulkanut- } \\ & \text { brudd, jordskjelv og sikkert andre ting } \\ \text { sp4: (MAN) } & \text { Hvis } b \text {, så ikke-c }\end{array}$

I dette eksemplet innrømmer respondenten at det meste av klimaendringene kommer fra menneskene, samtidig som naturlige faktorer presenteres som mer relevante i den innrømmende strukturen. Dette kommer av at mengdesuttrykket det meste brukes i argument $a$, mens uttrykket mye brukes i argument $b$. I motsetning til strukturen i eksempel (6) ser det med andre ord ut til at argumentasjonen orienteres mot passivitet, til tross for kategoritilhørigheten.

Blant de 64 svarene finner vi som nevnt 22 innrømmende konstruksjoner, alle bygd opp rundt konnektoren men. Tabell 2 viser hvordan de fordeler seg mellom betydningskategoriene:

\begin{tabular}{cccc}
\hline $\begin{array}{c}\text { 1. Natur og } \\
\text { mennesker likestilt }\end{array}$ & $\begin{array}{c}\text { 2.Natur viktigere } \\
\text { enn menneske }\end{array}$ & $\begin{array}{c}\text { 3.Mennesker vikti- } \\
\text { gere enn natur }\end{array}$ & $\begin{array}{c}\text { 4.Usikker- } \\
\text { het }\end{array}$ \\
\hline 4 & 9 & 6 & 3 \\
\hline
\end{tabular}

TABELL 2. FORDELING AV MEN MELLOM BETYDNINGSKATEGORIER

Blant disse forekomstene er det 15 som setter natur og mennesker opp mot hverandre i den innrømmende strukturen ' $a$ men $b$ '. I disse tilfellene er det en klar 
fordeling i argumentativ tyngde mellom natur og mennesker, fordi konnektorens logisk-semantiske instruksjoner tilsier at argument $b$ veier tyngst. Spørsmålet er altså hvordan disse konstruksjonene fordeler seg ikke bare mellom de forskjellige svarkategoriene, men også mellom forskjellige typer argumentativ orientering: mennesker eller natur (se tabell 3).

\begin{tabular}{|c|c|c|c|c|c|c|c|}
\hline \multicolumn{2}{|c|}{$\begin{array}{c}\text { 1. Natur og } \\
\text { mennesker likes- } \\
\text { tilt }\end{array}$} & \multicolumn{2}{|c|}{$\begin{array}{l}\text { 2. Natur viktigere } \\
\text { enn mennesker }\end{array}$} & \multicolumn{2}{|c|}{$\begin{array}{l}\text { 3. Mennesker } \\
\text { viktigere enn na- } \\
\text { tur }\end{array}$} & \multicolumn{2}{|c|}{ 4. Usikkerhet } \\
\hline $\begin{array}{c}\text { Natur } \\
\text { mest } \\
\text { rele- } \\
\text { vant }\end{array}$ & $\begin{array}{l}\text { Mennes- } \\
\text { ker mest } \\
\text { relevant }\end{array}$ & $\begin{array}{c}\text { Natur } \\
\text { mest } \\
\text { rele- } \\
\text { vant }\end{array}$ & $\begin{array}{l}\text { Mennes- } \\
\text { ker mest } \\
\text { relevant }\end{array}$ & $\begin{array}{c}\text { Natur } \\
\text { mest } \\
\text { rele- } \\
\text { vant }\end{array}$ & $\begin{array}{l}\text { Mennes- } \\
\text { ker mest } \\
\text { relevant }\end{array}$ & $\begin{array}{c}\text { Natur } \\
\text { mest } \\
\text { rele- } \\
\text { vant }\end{array}$ & $\begin{array}{l}\text { Mennes- } \\
\text { ker mest } \\
\text { relevant }\end{array}$ \\
\hline 1 & 2 & 1 & 6 & 2 & 3 & 0 & 0 \\
\hline
\end{tabular}

TABELL 3. INNRØMMENDE KONSTRUKSJONER: ARGUMENTATIV ORIENTERING INNENFOR FORSKJELLIGE BETYDNINGSKATEGORIER

Tallene i kategori 2 og 3 er spesielt interessante, fordi de ikke antyder noen korrelasjon mellom kategoritilhørighet og argumentativ orientering. Som nevnt tidligere er utvalget for begrenset til å være statistisk signifikant, men dette forhindrer oss likevel ikke i å trekke en allmenngyldig konklusjon: Språket har mekanismer som tillater oss å betegne én faktor som større eller viktigere enn en annen, samtidig som den andre faktoren har forrang i en gitt argumentativ kontekst. Dette ser vi spesielt hyppig innenfor kategori 2 «natur viktigere enn mennesker», hvor seks av syv innrømmende konstruksjoner fremstiller mennesker som den mest argumentativt relevante faktoren. Eksempel (6) faller inn under denne kategorien, i tillegg til følgende eksempler:

(8) a. Jeg mener vi er inne i en klimaendring. Tror at det er en naturlig utvikling i jordens levetid, men at mennesket har påvirkning slik at utviklingen skjer raskere.

b. At jorden er på vei inn i et klimaskifte, naturskapt men også på virket noe av menneskene

c. Klimaendringer er en naturlig prosess, men mennesker øker far ten på prosessen. Alle land må gjøre en innsats for miljøet, stoppe forurensing, og forberede seg på konsekvensene.

Gjennom bruken av den innrømmende konnektoren men, orienterer altså flere av respondentene sin argumentasjon mot ofte implisitte konklusjoner som ikke nødvendigvis svarer til den betydningskategorien som svaret inngår i. Et slikt 
funn kan også være politisk relevant, fordi det gir en forståelse av at selv oppfatninger om at klimaendringer er primært naturlige kan utgjøre et grunnlag for aksept om at politisk handling må til, såfremt det er fundamental enighet om at mennesker spiller en rolle som drivkraft for klimaendringene.

I en mer dyptgående epistemisk tilnærming, som vi ikke kan gå inn på her, ville det være interessant å se nærmere på en rekke svar som uttrykker usikkerhet på forskjellige måter. Det kan være gjennom direkte eller retoriske spørsmål eller gjennom ulike leksikalske kombinasjoner, slik som i disse eksemplene: «Menneskeskapt eller naturlig?»; «Usikkerhet. Noe skjer med klimaet, men jeg er usikker på årsak. Finner ikke ro i noen av leirene "naturlige skiftninger" eller "menneskeskapte endringer".»; «Menneskeskapt eller noko som ville skjedd likavel? Naturen er større enn det me kan skapa.»; «Er det virkelig påvirket av oss eller er det en naturlig endring?».

[5] LEKSIKALSK-SEMANTISK ANALYSE AV HVILKEN PLASS NATUREN HAR I FOLKS LIV OG LEVEMÅTE

I denne delen skal vi se nærmere på språklig representasjon av evaluering ('god'/'dårlig') i åpne tekstsvar om motivasjon for livsstilsendring for å begrense skadelige klimaendringer. Av plasshensyn behandler vi språklige uttrykk for følelser som en underkategori av evaluering, og vi undersøker hvordan uttrykk for henholdsvis evaluering og følelser virker sammen, og hvordan dette kan knyttes til en overordnet innramming av problemområdet. På grunn av materialets begrensete størrelse utfører vi en kvalitativ, eksplorativ analyse for å finne trekk som representerer evaluering og følelser, og som kan brukes som grunnlag for mer utvidete analyser av et større materiale i senere studier.

Av de 74 svarene er 19 (mer eller mindre) nøytrale, 13 inneholder både positive og negative uttrykk, 16 er positivt orientert, mens 26 er negativt orientert. Det er altså en svak overvekt av negativ orientering, men materialets størrelse gjør at vi må ta forbehold med hensyn til hvordan dette kan tolkes.

Nøytrale svartekster preges av liten eller ingen grad av evaluerende uttrykk, og en forenklet, «oppramsende» syntaktisk struktur, som i eksempel (9):

(9) Faktaopplysninger fra nrk om klimaendringer Naturprogrammer på nrk og Netflix Ungene etter hva de har lært på skolen

Svar som inneholder både positive og negative uttrykk har ikke en entydig evaluerende orientering. Dette ser vi illustrert i eksempel (10), som inneholder positivt orienterte uttrykk (motivert, omtanke, verne om), men også negativt orienterte (miljøbelastning, overflødig): 
(10) Stort personlig forbruk medfører miljøbelastning. Mye av mitt forbruk er overflødig. Jeg blir motivert av omtanke for livet i naturen, og reduserer gjerne mitt forbruk for å verne om naturlig liv.

Dersom et svar er positivt eller negativt orientert, er dette et resultat av en evaluerende prosodi, hvor flere språklige uttrykk sammen uttrykker den positive eller negative orienteringen. Eksempel (11) illustrerer en evaluerende prosodi med positiv orientering. Prosodien skapes av vekselvirkningen mellom leksikalske uttrykk som har en iboende positiv verdi, og som har som hovedfunksjon nettopp å evaluere, som adjektivet godt i tillegg til det grammatiske trekket komparativ (bedre) så vel som uttrykk som ikke har en iboende positiv verdi, men som tilordnes en positiv verdi i kontekst (bevare, gi, muligheter):

Bevare natur. Gi kommende generasjoner muligheter for et godt liv. Bedre helse.

Uttrykket kommende generasjoner har en uklar status. Sammenlikner vi med Norsk aviskorpus, finner vi at uttrykket brukes som en begrunnelse for politisk handling, i all hovedsak når det gjelder natur- og miljøvern, men også innen økonomi, idrett og kulturminnevern, som vist i Figur 1, og i eksempler som «Det vil trygge velferden også for fremtidige generasjoner». Uttrykket fremstår dermed ikke som evaluerende i snever forstand, men heller som uttrykk for et etisk prinsipp.

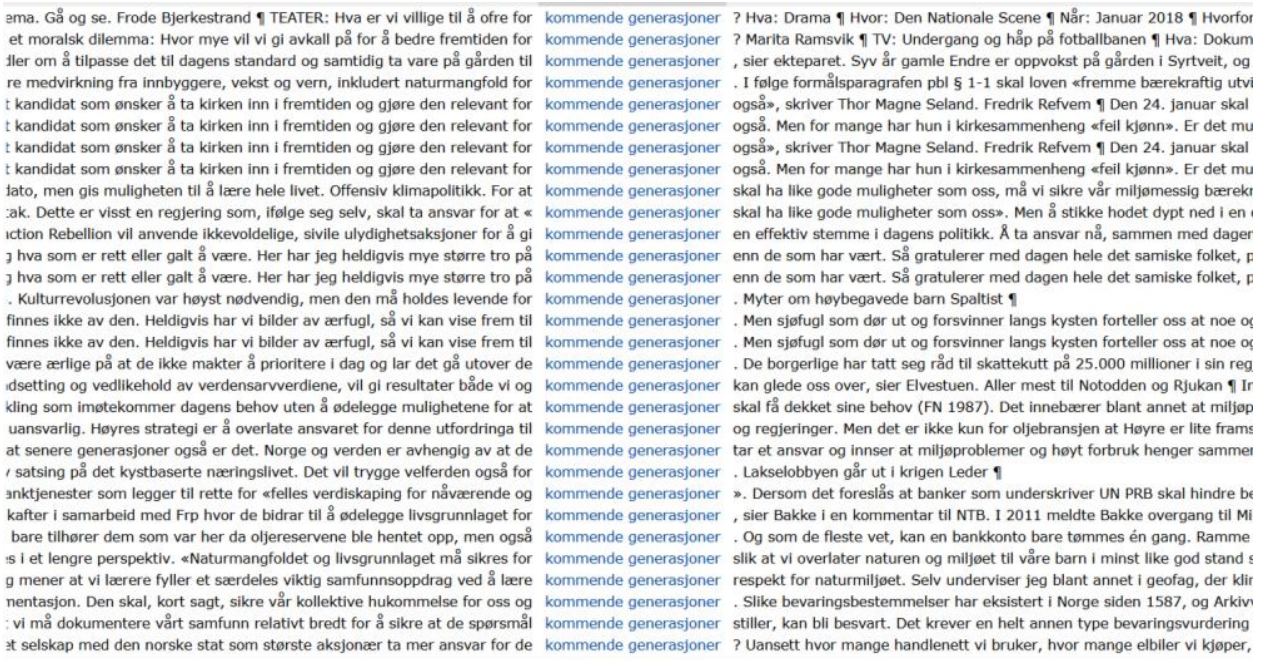

FIGUR 1. KWIC-KONKORDANSER FOR KOMMENDE GENERASJONER, NORSK AVISKORPUS 
Tekstene som er negativt orientert preges tilsvarende av en negativt evaluerende prosodi, som i eksempel (12), hvor det iboende negative uttrykket negativt opptrer med de konvensjonelt negative uttrykkene kast-bruk (bruk og kast) og søppel:

(12) Klimaendringer som har foregått over mange år, negativ med kast-bruk holdninger. Natur og dyreliv som skal bevares og konsekvensen av søppel og plast som blir brukt. Alle burde gjøre mye mer

I dette eksempelet er også uttrykket plast interessant. Etter natur* og søppel er plast det leksikalske ordet som opptrer hyppigst i materialet (24 forekomster). I vårt korpus er det også tydelig negativt assosiert, selv om det ikke har en iboende negativ verdi, slik søppel har. Sammenligner vi med Norsk aviskorpus, finner vi også en negativ evaluering av plast i 2019-utvalget, med fokus på plast som avfallsproblem. Sammenligner vi imidlertid med Norsk aviskorpus for 1998 finner vi at plast brukes i nøytral betydning, det vil si at det er snakk om plast som materiale, og dets ulike bruksområder. Dette tyder på at det har skjedd en semantisk glidning i allmennspråket i løpet av perioden 1998-2019. Vi mener å se at denne tendensen blir forsterket $\mathrm{i}$ vårt materiale, hvor plast systematisk inngår i negativt evaluerende prosodier. Det kan være grunn til å knytte denne språklige endringen til den såkalte «Plasthvalen», en gåsenebbhval som strandet på Sotra i 2017 med en stor mengde plast i magen. Denne hendelsen fikk stor oppmerksomhet og satte for alvor problemet med plastforsøpling på dagsordenen, $\mathrm{i}$ tillegg til økende bevissthet om mikroplast.

Svarene som kjennetegnes av evaluerende prosodi er gjerne også preget av språklige uttrykk for følelser. Det er et tydelig samvirke mellom disse to typene språklige uttrykk, som gjør at de gjensidig forsterker hverandre. I det følgende skal vi se nærmere på svar hvor følelsesuttrykk er til stede.

Også følelsesorienterte uttrykk struktureres rundt den evaluerende aksen (god/dårlig), og vi kan skille mellom de som vektlegger negative følelser som frykt og skam, og de som vektlegger positive følelser som kjærlighet. Negative følelser knyttes gjerne også til negativ evaluering, som i eksempel (13), hvor uttrykk for redsel (skremmende, oppriktig redd) kombineres med uttrykk for negativ evaluering (ekstremver, reduseres kraftig, det vanvittige forbruket, søppelmengden):

(13) Ekstremvær som oppleves i dag av mange mennesker i verden. Arts mangfoldet som reduseres kraftig. FNs klimapanel og FNs naturpanels skremmende rapporter som vi MÅ ta på alvor. Det vanvittige forbruket vårt og søppelmengden i verden. Jeg har barn, og er oppriktig redd for hvordan de, og deres barn igjen, vil få det i framtida. 
I dette eksempelet ser vi også hvordan følelsesuttrykkene og den negative evalueringen kobles til ulike språklige og typografiske uttrykk for intensitet (mange, kraftig, MÅ, vanvittige, oppriktig) som samlet styrker inntrykket av uro og akutt miljøfare som respondenten gir uttrykk for. Tilsvarende eksempler finner vi for positivt orienterte følelser, som i (14), hvor valget om livsstilsendring begrunnes i positive følelser som takknemlighet og kjoerlighet:

(14) Takknemlighet for det man har og kjærlighet til naturen

Uttrykket «det man har» er ikke iboende positivt, men det inngår her i en positivt evaluerende prosodi. Sammenligner vi med Norsk aviskorpus ser vi at uttrykket brukes til å signalisere nøysomhet og omsorg for tingene sine, gjerne i kontrast til mer sløsende og risikopreget adferd, som vi ser av de seks forekomstene i korpuset fra 2019:

. Det var nok redningen, sier Tveiten. - En vil gjerne redde det man har . Tross alt sammen, har det gått veldig bra. Ingen ble skadd 2019-01-25

ælt - Det absolutt viktigste man kan gjøre er å ta vare på det man har og kjøpe mindre nytt. Dersom noe har mistet fasongen kan ma 2019-05-31

t er lettere å finne penger til å bygge noe nytt enn å fikse det man har . Vannet $\mathrm{i}$ krana er jo der, helt til det ikke er det mer, sk 2019-09-02

det lettere å finne penger til å bygge noe nytt enn å fikse det man har . Dette er en gigantisk utfordring for politikken og dermed 2019-09-02

6 at det var et stort fokus på bærekraft og etterbruk. Bruke det man har og tilpasse konseptene deretter. Det innebærer at ambisjone 2019-10-04

rbruker, kan fastetiden gjøre mennesker mer takknemlige over det man har . Noe av tanken bak den lille fasten er derfor å gjenoppdage 2019-12-01

Det er altså snakk om et generelt etisk prinsipp, som oppvurderes gjennom å inngå i den positivt evaluerende prosodien.

I tillegg til svar hvor følelsesuttrykk inngår i henholdsvis negativt eller positivt orienterte prosodier, finner vi også svar som generelt har en sterk følelsesdimensjon, både når det gjelder negative og positive aspekter som i eksempel (15), hvor både frykt og kjwrlighet oppgis som motivasjon for livsstilsendring:

(15) Kjærlighet til den frie og uberørte naturen Frykt for at våre barn skal 
oppleve sammenbrudd, både i naturen og i sivilisasjonen.

Følelsesuttrykkene kobles også til uttrykk for positiv og negativ evaluering henholdsvis frie og sammenbrudd. Når det gjelder uberørte viser sammenligning med Norsk aviskorpus at uttrykket er positivt når det brukes om naturen ( $\AA$ oppsøke uberørt natur er som å komme hjem»), men oftest negativt når det brukes om mennesker, og spesielt om kriminelle («Terrorsiktet russer fremstår uberørt etter knivangrep»).

Andre svar har derimot sterkere fokus på den kognitive dimensjonen, og har lite «følelsesuttrykk»:

(16) Jeg har lyttet til råd fra klimaforskere som legger fram vitenskapelige data. Jeg mener at naturvernerne krisemaksimerer, og er lite truverdig.

Dette eksempelet preges av mer kognitivt orienterte verb/verbuttrykk (lyttet til, mener) og referanser til ekspertkunnskap (råd, klimaforskere, vitenskapelige data). Sammenlikner vi med Norsk aviskorpus fremgår det imidlertid at verbet krisemaksimere brukes om adferd det er all grunn til å unngå («de skal passe seg for å krisemaksimere», «advarer mot å krisemaksimere»). Sammen med uttrykket «lite truverdig» uttrykkes dermed en negativt evaluerende prosodi, selv om innrammingen av svaret er mer kognitivt eller epistemisk enn følelsesmessig orientert.

Eksemplene på følelsesuttrykk viser også hvordan naturen bidrar til innrammingen av problemet, som i materialet er tett koblet til en forståelse av at vi må 'ta vare på naturen', ut fra en empati eller solidaritet med naturen, men også med kommende generasjoner, som i eksempel (17):

Jeg føler et stort ansvar for naturen og alt liv, og synes det er fryktelig å se hvordan mennesket har redusert og ødelagt leveforholdene for annet liv. Enkeltmennesket må ta ansvar og akseptere såkalt reduksjon i levestandard. Slik jeg ser det er betydelige deler av vårt forbruk destruktivt også for mennesket. Jeg er overbevist om at en levemåte mer i pakt med naturen vil gi mening og verdi langt ut over det vi i dag opplever i store deler av verden.

Oppsummert tyder denne eksplorative analysen av et begrenset tekstmateriale på at livsstilsendring evalueres både positivt og negativt, men også at en del av respondentene er mer nøytrale. Når det skjer negativ/positiv evaluering i form av prosodier, det vil si at evalueringen gjentas over flere uttrykk, følges de gjerne av følelsesladete uttrykk. Selv om materialet vårt er lite, er det interessant at de som begrunner livsstilsendring på denne måten også gjerne argumenterer med 
et etisk ansvar for naturen og empati med andre arter og kommende generasjoner, altså en innramming av problemet i tråd med den "grønne radikalismen» nevnt over. Svar som er mer nøytrale uttrykker gjerne en mer pragmatisk tilnærming til problemet, i form av praktiske tiltak som kan gjennomføres for å motvirke skadelige klimaendringer, noe som er mer i tråd med «bærekraftig utvikling» og «økologisk modernisering» slik det beskrives hos Dryzek (2013).

\section{[6] DISKUSJON}

Materialet fra de to spørreundersøkelsene omfatter forskjellige språklige fenomener pga. spørsmålet som stilles. I undersøkelsen fra 2018 er spørsmålet åpent: «Hva tenker du når du hører eller leser ordet 'klimaendring'?». De svarene som inkluderte både natur* og menneske* hadde en klar tendens til å diskutere spørsmålet om hvilken av de to faktorene som var den viktigste årsaken til klimaendringene. I disse avveiningene spilte språklige polyfonimarkører en viktig rolle, ved å skape blant annet benektende og innrømmende relasjoner mellom respondentene og andres synspunkter.

I 2019 fikk respondentene følgende spørsmål: «Har du endret din levemåte for å bidra til å begrense skadelige klimaendringer?» De som svarte positivt på dette ble deretter bedt om å utdype: «Vi vil gjerne at du forteller oss hva som har motivert deg til å endre din levemåte.» Her ble det også lagt opp til diskusjoner, men i motsetning til undersøkelsen fra 2018 er det ikke snakk om en epistemisk diskusjon, men om personlige valg og verdier. For å fange opp nyansene i respondentenes drøfting var det mest hensiktsmessig å foreta en leksikalsk-semantisk analyse, som tar for seg den språklige konstruksjonen av evaluering og følelser. Forskjellene mellom de to undersøkelsene illustrerer altså at den teoretisk-metodiske tilnærmingen til et språklig materiale ikke kan velges uavhengig av materialets egenart, men bør gjøres ut fra hensyn til tekstenes tematikk og analysens problemstilling.

Videre belyser denne todelte tilnærmingen den betydelige kompleksiteten i klimaspørsmålet. Som forbrukere og deltakere i et demokrati må man ta stilling til et fenomen som er vanskelig å forstå, som har alvorlige men usikre konsekvenser for fremtiden, og som involverer vanskelige politiske og personlige valg. De åpne spørreundersøkelsene fanger opp denne kompleksiteten på forskjellig vis. For det første viser spørsmålet om naturlig versus menneskelig påvirkning en usikkerhet som manifesterer seg i uoverensstemmelser mellom det som er viktigst og det som er argumentativt mest relevant. For det andre er det vesentlig variasjon i respondentenes emosjonelle involvering i spørsmålet om endring i levemåte. 
I denne artikkelen har vi også ønsket å undersøke om ulike ideologiske posisjoner kommer til syne når respondentene fritt reflekterer over klimaendringer. Er det slik at respondentene forholder seg til posisjonene «bærekraftig utvikling» og «økologisk modernisering» som vi beskrev i introduksjonen, eller finner vi også mer radikale posisjoner som kan knyttes til «grønn radikalisme»? På grunn av materialets størrelse vil vi heller ikke her kvantifisere, men kvalitativt observere hva som kjennetegner de ulike stemmene i vårt materiale. Den kvalitative analysen i seksjon 5 , av svar på spørsmålet om hva som har motivert til livsstilsendring for å bidra til å begrense skadelige klimaendringer, viser likevel at flere posisjoner er tilstede blant respondentene. Mens en del av respondentene peker på tiltak som befinner seg innenfor dagens politiske rammer, som resirkulering og elbiler, viser mange til behovet for nedvekst (degrowth) og understreker hvordan miljøproblemene rammer andre arter. Denne typen svar innebærer dermed et brudd med vekstprinsippet og det antroposentriske perspektivet som er innbakt $i$ andre ideologiske tilnærminger til miljøspørsmålet. Det er interessant $\mathrm{i}$ vår sammenheng at slike utsagn gjerne er koblet på språklige uttrykk for evaluering, og sammenhengen mellom evaluering, språklige uttrykk for følelser og «grønn radikalisme» vil være interessant å undersøke videre i fremtidig forskning.

En fremtidig studie vil også mer helhetlig kunne undersøke klimaspørsmålets kompleksitet nærmere, ved å kombinere de to spørsmålene i en og samme spørreundersøkelse, med mål om å undersøke eventuelle korrelasjoner mellom epistemiske og emosjonelle perspektiver hos respondentene.

\section{REFERANSER}

Andersen, Gisle. 2017. Parlamentets natur. Utviklingen av norsk miljø- og petroleumspolitikk (1945-2013). Universitetsforlaget.

http://dx.doi.org.10.18261/9788215028132-2017

Andersen, Gisle \& Knut Hofland. 2012. Building a large corpus based on newspapers from the web. I Gisle Andersen (red.) Exploring Newspaper Language, 1-28. Amsterdam/New York: John Benjamins.

Breeze, Ruth. 2019. Emotion in politics: Affective-discursive practices in UKIP and Labour. Discourse \& Society 30(1). 24-43.

Dryzek, John S. 2013 [1997]. The politics of the earth: Environmental discourses. Oxford: Oxford University Press.

Ducrot, Oswald. 1984. Le Dire et le Dit. Paris: Éditions de Minuit. 
Fløttum, Kjersti (red.). 2017. The role of language in the climate change debate. New York: Routledge.

Fløttum, Kjersti, Trine Dahl, \& Torodd Kinn. 2006. Academic Voices - across languages and disciplines. Amsterdam: John Benjamins Publishing Company.

Gjerstad, Øyvind. 2011. La polyphonie discursive. Pour un dialogisme ancré dans la langue et dans l'interaction. Doctoral dissertation. Bergen: University of Bergen.

Hunston, Susan. 2004. Counting the uncountable: Problems of identifying evaluation in a text and in a corpus. Corpora and discourse 9. 157-188.

Hunston, Susab. 2007a. Using a corpus to investigate stance quantitatively and qualitatively. Stancetaking in discourse: Subjectivity, evaluation, interaction 164. 27-48.

Hunston, Susan. 2007b. Semantic prosody revisited. International Journal of Corpus Linguistics 12(2). 249-268.

Langaas, Runa F., Kjersti Fløttum \& Øyvind Gjerstad. 2020. Expressing one's conceptions of lifestyle in a climate perspective. Cahiers de praxématique 73.

Louw, Bill. 1993. Irony in the text or insincerity in the writer? The diagnostic potential of semantic prosodies. In Mona Baker, Gill Francis \& Elena TogniniBonelli (red.), Text and technology: In honour of John Sinclair, 157-177. Amsterdam: John Benjamins.

Nølke, Henning, Kjersti Fløttum \& Coco Norén. 2004. ScaPoLine. La théorie scandinave de la polyphonie linguistique. Paris : Kimé.

Partington, Alan. 2004. Utterly content in each other's company: Semantic prosody and semantic preference. International Journal of Corpus Linguistics 9(1). 131-156.

Partington, Alan, Alison Duguid \& Charlotte Taylor. 2013. Patterns and meanings in discourse: Theory and practice in corpus-assisted discourse studies (CADS) (Vol. 55). Amsterdam: John Benjamins Publishing Company.

Sinclair, John. 1987. Looking Up. London \& Glasgow: Collins.

Stoneman, Paul, Patrick Sturgis, \& Nick Allum. 2012. Exploring Public Discourses About Emerging Technologies Through Statistical Clustering of Open-ended Survey Questions. Public Understanding of Science 22(7). 850-868. 
Tvinnereim, Endre \& Kjersti Fløttum. 2015. Explaining topic prevalence in answers to open-ended survey questions about climate change. Nature Climate Change 5. 744-747.

Tvinnereim, Endre, Kjersti Fløttum, Øyvind Gjerstad, Mikael P. Johannesson \& Åsta D. Nordø. 2017. Citizens' preferences for tackling climate change. Quantitative and qualitative analyses of their freely formulated solutions. Global Environmental Change 46. 34-41

Wierzbicka, Anna. 1992. Talking about emotions: Semantics, culture, and cognition. Cognition \& Emotion 6(3-4). 285-319.

Kjersti Fløttum

$\mathrm{UiB}$

kjersti.flottum@uib.no

Øyvind Gjerstad

UiB

oyvind.gjerstad@uib.no

Anje Müller Gjesdal

Hiø

anje.m.gjesdal@hiof.no 